\title{
PEGARUH JENIS KELAMIN, LATAR BELAKANG PENDIDIKAN DAN PEKERJAAN ORANG TUA TERHADAP HASIL BELAJAR PROGRAM STUDI PENDIDIKAN PANCASILA DAN KEWARGANEGARAAN IKIP-PGRI PONTIANAK
}

\author{
Zuldafrial ${ }^{1}$, Muhammad Anwar Rube' I ${ }^{2}$ \\ 1,2,3 Program Studi PPKN Fakultas Ilmu Pendidikan dan Pengetahuan Sosial IKIP PGRI Pontianak \\ Jl. Ampera Nomor 88 Pontianak-78116, Telepon (0561) 748219 Fax. (0561) 6589855 \\ Email: zuldaf55@yahoo.co.id
}

\begin{abstract}
Abstrak
Penelitian ini, bertujuan untuk mengetahui pengaruh jenis kelamin, latar belakang pendidikan dan pekerjaan orang tua hasil belajar Mahasiswa program studi Pancasila dan Kewarganegaraan IKIP-PGRI Pontianak. Metode penelitian ini metode ex post facto dengan desain factorial $2 \times 2 \times 2$. Berdasarkan hasil pengolahan data, maka dapat disimpulkan hasil penelitian ini sesuai dengan rumusan masalah sebagai berikut: (1) Terdapat perbedaan yang signifikan dalam hasil belajar antara Mahasiswa dan mahasiswi. Mahasiswa memiliki hasil belajar lebih baik dari kelompok Mahasiswi, (2) Terdapat perbedaan yang signifikan dalam hasil belajar antara Mahasiswa-mahasiswi yang berasal dari SLTA Negeri dan mahasiswa-mahasiwi yang berasal dari SLTA swasta. Kelompok mahasiswa- mahasiswi yang berasal dari SLTA Negeri hasil belajarnya lebih rendah dari hasil belajar kelompok mahasiswa- mahasiswi yang berasal dari SLTA Swasta, (3) Terdapat perbedaan yang signifikan dalam hasil belajar antara Mahasiswa-mahasiswi yang pekerjaan orang tuanya Pegawai Negeri dan mahasiswa-mahasiwi yang pekerjaan orang tuanya Pegawai Swasta. kelompok mahasiswa-mahasiswi yang pekerjaan orang tuanya Pegawai Negeri hasil belajarnya lebih tinggi dari hasil belajar kelompok mahasiswa-mahasiswi yang pekerjaan orang tuanya Pegawai Swasta, (4) Tidak terdapat perbedaan yang signifikan dalam hasil belajar mahasiswa-mahasiswi berdasarkan interaksi jenis kelamin dan asal sekolah, (5) Tidak terdapat perbedaan yang signifikan dalam hasil belajar mahasiswa-maahasiswi berdasarkan interaksi jenis kelamin dan pekerjaan orang tua, (6) Tidak terdapat perbedaan yang signifikan dalam hasil belajar Mahasiswa-mahasiswi berdasarkan interaksi asal sekolah dan pekerjaan orang tua, (7) Tidak terdapat perbedaan yang signifikan dalam hasil belajar mahasiswa-mahasiswi berdasarkan interaksi jenis kelamin, asal sekolah dan pekerjaan orang tua.
\end{abstract}

Kata Kunci: Jenis Kelamin, Latar belakang Pendidikan, Pekerjaan Orang Tua, Hasil Belajar

\begin{abstract}
This study aims to determine the effect, educational background and work of parent on the learning outcomes of students of the PPKn study Program IKIP-PGRI Pontianak.This research method with factorial $2 \times 2 \times 2$ design. The independent variables in this study are: (a) Sex; (b) Educational background: (c) Parental work. The dependent variable is learning outcomes. Control variable are: (a) 2014-2015 academic year; (b) Semester two learning outcomes. Based on the result of data processing, it is concluded that the resultof this study are in accordance with the formulation of problem as follows: (1) There are significant differences in learning outcomes between students and college student. Students have better learning outcomes than female students. (2) There are significant differences in learning outcomes between students from public high schools and students from private high schools. The group of students came from public high schools, the learning outcomes were lower than the learning outcomes of group of students from private high schools. (3) the are significants differenes in learning outcomes between students whose parents work are civil servants and students whose parents work are private employees. A group of students whose work is parents of civil servants, higher learning outcomes from the learning outcomes of groups of students whose parents work are private employees. (4) There is no significant differences in student learning outcomes based on the interaction of sex and origin of the school. (5) There is no significant differences in student learning outcomes based on gender interaction and parent work. (6) There is no significant differences in student learning outcomes based on the interaction of school origin and the work of parents. (7) There is nno significant differences in student learning outcomes based on the interaction of gender, origin of school and parent.
\end{abstract}

Keywords: Gender, Educational background, Parent's work, Learning outcomes 


\section{PENDAHULUAN}

Belajar pada dasarnya adalah merupakan proses mental, karena orang yang belajar perlu memikir, menganalisa, mensentesa, mengingat dan mengambil kesimpulan dari apa yang dipelajari. Menurut J.L. Mursell dalam proses kegiatan belajar itu, selalu terdapat aspek-aspek sebagai berikut: "Pertama, Bahwa belajar itu bertujuan. Adanya tujuan dalam belajar itu akan nyata apabila peserta didik dihadapkan pada masalah. Ia bertujuan untuk memecahkan masalah tersebut. Kedua, Bahwa belajar itu prosesnya berlangsung dengan penyelidikan dan penemuan, bukan berlangsung secara repititif. Seorang yang belajar perlu dihadapkan pada suatu masalah. Agar dapat memecahkan masalah itu, perlu adanya penyelidikan dan penemuan pemecahannya. Ketiga, Bahwa hasil belajar munculnya pemahaman, munculnya pengertian, munculnya respon yang berakal. Kempat, Bahwa hasil belajar itu tidak hanya terikat pada situasi munculnya pemahaman saja, tapi dapat digunakan pada situasi yang lain ".

Berdasarkan pendapat di atas jelas bahwa belajar dikatakan berhasil, apabila seseorang yang belajar benar-benar telah memahami apa yang dipelajarinya. Belajar dikatakan gagal, apabila seseorang yang belajar tidak memahami apa yang dipelajarinya. Proses belajar itu berlangsung dari tidak tahu menjadi faham, melalui tingkatan-tingkatan sebagai berikut: (1) Tidak tahu sama sekali; (2) Bimbang atau ragu; (3) Mempunyai perkiraan; (4) Mempunyai endapat; (5) Berkeyakinan; (6) Berkepastian.

Di dalam pendidikan formal berupa sekolah, hasil belajar itu dinyatakan dengan nilai. Nilai itu dikelsifikasikan sangat baik, baik, sedang dan kurang. Pengkelasifikasian hasil belajar itu untuk menunjukan tingkat penguasaan bahan yang telah dipelajari oleh siswa atau mahsiswa melalui suatu penilaian hasil belajar.

Keberhasilan seseorang dalam belajar umumnya dipengaruhi oleh berbagai faktor yang dapat dikelsifikasikan menjadi dua faktor yaitu faktor internal dan faktor eksternal. Faktor internal adalah faktor yang berasal dari dalam diri seseorang. Sedangkan faktor eksternal adalah faktor yang berasal dari luar diri seseorang. Fakta dengan adanya dua realitas ini, yakni realitas individu yang mengandung faktor internal dan realitas lingkungan yang mengandung faktor eksternal, maka perlu kirannya diketengahkan teori perkembangan individu yaitu teori nativisme, teori empirisme dan teori konvergensi (Fudyartanta, 1970: 57)

1. Teori Nativisme

Nativisme berasal dari kata "nativis" yang artinya pembawaan. Teori ini berpendapat pembawaan atau nativius lah yang menentukan perkembangan individu. Individu yang pembawaanya baik maka perkembangannya akan baik pula. Jadi jika seseorang mempunyai 
intelegensi yang tinggi maka hasil belaajarnya juga akan tinggi.sebaliknay demikian pula, jika intelegensi seseorang rendah, maka hasil belajarnya juga akan rendah.

2. Teori Empirisme

Empirisme berasal dari kata "empiris" yang artinya pengalaman. Teori ini berpendapat bahwa perkembangan individu ditentukan oleh pengalaman yang diperoleh individu. Karena pengalaman datangnya dari luar, maka faktor eksternallah yang menentukan perkembangan individu. Teori ini menekankan bahwa perkembangan individu diutentukan oleh pengaruh lingkungan. Jadi hasil belajar seseorang akan baik, jika lingkungannya baik dan hasil belajar sesorang menjadi kurang baik, jika lingkungannya tidak menunjang.

3. Teori Konvergensi

Teori ini merupakan perpaduan daripada teori nativisme dan teori empirisme. Teori ini berpendapat bahwa perkembangan individu ditentukan oleh pembawaan dan lingkungan. BaIk faktor internal maupun eksternal kedua-duannya mempengaruhi dan memegang peranan penting dalam perkembangan individu. Hasil belajar yang dicapai seseorang adalah merupakan hasil kerja sama antara faktor internal dan eksternal.

Dari ketiga teori perkembangan individu itu, maka teori terakhirlah yang menjadi pegangan kita bahwa perkembangan seseorang ditentukan oleh faktor internal dan faktor eksternal. Oleh karena itu hasil belajar yang dicapai oleh sesorang merupakan perpaduan dari kedua faktor ini. Sehubungan dengan itu Masrun dan Mulyani (1976:51) mengemukakan bahwa faktor-faktor yang dapat mempengaruhi hasil belajar seseorang seseorang antara lain: (1) Kemampuan pembawaan; (2) Kondisi fisik orang yang belajar; (3) Kondisi psikis; (4) Kemauan belajar; (5) Sikap terhadap guru, mata pelajaran dan pengertian mereka mengenai kemajuan mereka sendiri.

1. Pembawaan

Telah kita sadari bahwa tidak ada dua orang yang sama, juga di dalam kemampuan. Tiap orang mempunyai potensi kemampuan sendiri-sendiri.Kemampuan pembawaan ini akan mempengaruhi hasil belajar individu. Sesorang yang mempunyai kemampuan pembawaan yang lebih, akan lebih mudah dan cepat belajar daripada mempunyai kemampuan yang rendah.Tapi dalam hal kitak tidak mengatakan kemampuan ini adalah faktor yang paling penting dalam belajar. Kekuranga dalam kemampuan pembawaan dapat diatasi dengan banyak cara. Umpamanya dengan menyediakan fasiltas belajar yang cukup, membuat latihan-latihan yang banyak dan lain-lain.

2. Kondisi fisik orang yang belajar 
Orang yang belajar tidak terlepas dari kondisi fisiknya. Menurut penelitian ternyata kondisi fisik mempengaruhi hasil belajar. Belajar dalam kondisi fisik yang segar tentu berbeda dengan belajar dalam kondisi fisik yang tidak sehat.

3. Kondisi psychis orang yang belajar

Selain kondisi fisik, kondisi psychis pun dapat mempengaruhi hasil belajar. Kondisi psychis yang baik banyak sebabnya, mungkin disebabkan oleh keadaan lingkungan, situasi rumah, keadaan ekonomi keluarga dan lain-lain. Ini semua menjadi gangguan dalam belajar.

4. Kemauan belajar

Kemauan memegang peranan penting dalam belajar. Adanya kemauan dapat mendorong belajar dan sebaliknya tidak adanya kemauan dalam belajar dapat memperlemah aktivitas belajar. Oleh karena itu untuk berhasil dalam belajar, diperlukan kemauan yang kuat, karena dengan kemamuan yang kuat individu terdorong untuk belajar.

5. Sikap terhadap guru, mata pelajaran dan pengertian mereka tentang kemajuan mereka sendiri

Sikap siswa atau mahasiswa terhadap guru atau dosen juga dapat mempengaruhi hasil belajar. Siswa atau mahasiswa kurang menyenangi guru atau dosennya tidak akan lancara belajar.Sebaliknya jika siswa atau mahasiswa menyenangi guru atau dosennya, ini akan membantu belajarnya. Disinilah perlu diperhatikan sikap guru atau dosen kepada siswa atau mahsiswanya. Sikap yang baik, ramah, mengenal siswa atau mahsiswa akan menjadi dorongan bagi siswa atau mahasiswa dalam belajarnya.

Sikap siswa atau mahasiswa terhadap mata pelajaran atau mata kuliah merupakan faktor yang penting. Mata pelajaran atau mata kuliah yang disenangi siswa atau mahasiswa akan lebih berhasil dipelajari daripada mata pelajaran atau mata kuliah yang kurang disenangi. Mata pelajaran atau mata kuliah dapat disenangi atau dibenci tergantung dari banyak faktor. Mungkin penyampaian guru atau dosen kurang menarik, mungkin disebabkan karena adanya kegagalan yang dialami siswa atau mahasiswa dalam mata pelajaran atau mata kuliah itu,dan mungkin pula karena sebab-sebab lainnya. Adanya pengertian tentang adanya kemajuan atau kemunduran dalam belajar, mendorong orang yang belajar untuk meningkatkan hasil belajarnya. Kemunduran yang dialami data dijadikan dorongan untuk memperbaikinya.

Selain faktor-faktor sebagaimana dikemukakan di atas, hasil belajar seseorang dapat pula dipengaruhi oleh pekerjaan orang tua, latar belakang pendidikan sebelumnya dan jenis kelamin.

1. Pekerjaan Orang Tua dan hasil Belajar

Jenis pekerjaan orang tua berpengaruh terhadap keberhasilan anak dalam belajar. Hal ini disebabkan karena jenis pekerjaan berkaitan erat dengan pendapatan, tingkat pendidikan, 
dan waktu orang tua dalam memperhatikan pendidikan anak-anak mereka. Hasil penelitin menunjukan bahwa terdapat hubungan antara jenis pekerjaan dengan kepedulian orang tua terhadap pendidikan anak di sekolah. Besarnya koefisen hubungan antara kedua variabel itu 0,90 sangat tinggi. Berdasar analisis tabulasi silang, diketahui bahwa orang tua mempunai jenis pekerjaan terampil, kepeduliannya terhadap pendidikan anak di sekolah lebih baik dibadingkan dengan orang tua yang bekerja pada jenis pekerjaan semi terampil. Orang tua yang bekerja pada jenis pekerjaan semi terampil labih baik kepeduliannya terhadap pendididiakn anaknya dibandingkan dengan orang tuan yang bekerja pada jenis pendidikan tidak terampil.(Zuldafrial, 2002: 69). Penelitian lainnya menunjukan bahwa teradapat hubungan positif antara jenis pekerjaan orang tua dengan prestasi belajar siswa di sekolah (Zuldafrial, 2004:156). Orang tua yang bekerja sebagai pegawai negeri mempunyai pengahsilan tetap yang dibawa pulang setiap bulan, Tingkat pendidikan umumnya cukup tinggi dan mempunyai waktu yang cukup untuk memperhatikan pendidikan anak-anaknya. Sedangkan orang tua yang bekerja sebagai karyawan swasta umumnya penghasilan tidak tetap, waktu bekerja tidak tetap dan tingkat pendidikanm bervariasi.

Oleh karena itu secara hipotesis dapat dikatakan bahwa hasil belajar mahasiwa atau mahasiswi yang latar belakang pekerjaan orang tuanya sebagai pegawai negeri tentu lebih baik dibandingkan dengan mahasiswa atau mahasiswa yang latar belakang perkerjaan orang tuanya sebagai karyawan swasta. Karena orang tua yang pekerjaannya sebagai pegawai negeri lebih dapat memenuhi kebutuhan anak-anaknya dalam belajar dalam bentuk perhatian atau kepedulian tehadap pendidikannya anak-anaknya dalam bentuk kongkritnya dapat memngontrol aktivitas belajar anaknya dan relatif mampu memenuhi biaya pendidikan anakanaknya.

2. Jenis Kelamin dan Hasil Belajar

Jenis kelamin dapat mempengaruhi hasil belajar sesorang. Jenis kelamin merupakan faktor pembawaan yang dibawa seseorang sejak ia dilahirkan. Jenis kelamin mempengaruhi sifat atau karekter sesorang. Karekter laki-laki umumnya tegas, rasional, cekatan dan ulet pantang menyerah. Karekter wanita lembut, emosional, lamban dan mudah menyerah.Namun demikian laki-laki punya sifat ceroboh, tidak sabar, dan kurang cermat. Berbeda dengan wanita yang punya sifat teliti, sabar dan cermat dalam melakukan sesuatu pekerjaan. Karekter dan sifat-sifat ini tentunya sedikit banyak akan mempengaruhi cara-cara belajar dan hasil belajar mahasiswa atau mahasiwi.

Sementara itu konstruksi sosial dari seksualitas, mengacu pada proses ketika ide-ide, prilaku dan kondisi seksual dintrepretasikan dan dipelajari, setiap manusia baik laki-laki Pengaruh Jenis Kelamin, Latar Belakang Pendidikan Dan Pekerjaan Orang Tua Terhadap Hasil 
maupun perempuan mengembangkan kapasitas seksualnya menurut aturan-aturan yang berlaku dalam masyarakat dan kebudayaannya. Ada larangan dan keharusan yang telah ditetapkan dalam masyaraat yang mempengaruhi prilaku mereka.(Anna Marie Wattie, 1996:184). Secara kemampuan akademis tidak ada perbedaan antara pria dan wanita, hanya faktor biologislah yang membedakan antara pria dan wanita, dimana secara kodrati wanita melahirkan dan menyusui anak. Semua peran yang dilakuan oleh laki-laki mampu juga dilakukan oleh wanita.

3. Latar Belakang Pendidikan dan Hasil Belajar

Latar belakang pendidikan sebelumnya dapat mempengaruhi hasil belajar seseorang. Sebab kualitas pembelajara yang diterima oleh sesorang dari suatu pendididkan akan menjadi dasar bagi seseorang untuk dapat mengikuti dengan baik pendidikan lanjutannya. Apa yang telah diketahui seseorang akan berfungsi sebagai filter yang akan membantu mereka dalam menentukan dan menaruh perhatian pada suatu informasi atau materi pelajaran yang disajikan (Rudiana, 2012:34). Oleh sebab itu pengalaman belalajar yang lalu berpengaruh terhadap keberhasilan belajar yang dilakukan pada saat sekarang ini. Kualitas pembelajaran yang kurang efektif yang diterima siswa sebelumnya menjadi salah satu faktor penghambat kegagalan siswa dalam megikuti pelajaran pada studi lanjutannya.

Seorang mahasiswa atau mahasiswi akan dapat belajar di suatu perguruan tinggi dengan baik, jika ia telah mendapatkan pendidikan ang baik pula pada saat menempuh pendidikan di sekolah menengah. Karena belajar adalah merupakan upaya menghubungkan pengetahuan yang telah kita memiliki dengan pengetahuan baru, respon yang berakal menyebabkan munculnya pemahaman, muncul insight yang menunjukan bahwa proses pembelajaran itu behasil. Jika sesuatu itu tidak memiliki relevansi atau bertentangan dengan kumpulan pengetahuan yang dimiliki seeorang, maka ia jarang sekali bisa bermakna. Hal menjadi sebab mengapa seseorang sangat sulit untuk memahami sesuatu pesoalan yang dipelajarinya.

Pendidikan pada Sekolah Menengah Negeri pada umumnya lebih baik dibandingkan dengan pendidikan di Sekolah Menenah Swasta. Sekolah Menengah Negeri sumber daya pendidikannya lebih terjamin seperti kualifikasi tenaga pengajar, fasilitas belajar dan pendanaan karena umumnya mendapat bantuan dari pemerintah Tidak demikian halnya dengan Sekolah Menengah Swasta sumber daya pendidikan umumnya jauh dari standar. Biaya pendidikan ditanggung oleh orang tua siswa yang pengelolaan dilakuan oleh suatu badan pengelola yang disebut yayasan. Dana pengelolaan dari orang tua siswa ini tidaklah cukup untuk dapat meningkatkan kiualitas pendidikan, karena penarikan dana yag terlalu 
mahal tidak sesuai dengan kemampuan orang tua menyebabkan sekolah tidak diminati oleh masyarakat. Data yang dilansir Menteri Pendidikan dan Kebudayaan (Mendikbud) Moh Nuh mengenai hasil Ujian Nasional (UN) untuk tingkat SMA/MA, menunjukkan sekolah-sekolah negeri masih lebih hebat dibanding sekolah swasta (http:rapendik.com/program/impag/1273 sekolah negeri-lebih hebat, diakses, jum'at, 5 september 2013)

Oleh karena itu dalam penelitian ini, peneliti tertarik untuk melihat apakah faktor pembawaan dan lingkungan memberikan pengaruh yang berarti terhadap hasil belajar peserta didik. Dalam penelitian ini dipilih mahasiswa program studi Pancasila dan Pendidikan Kewarganegaraan (PPKn) sebagai subjek kajian dalam penelitian ini. Sesuai dengan uraian pada latar belakang penelitian ini maka dirumuskan judul penelitian ini adalah " Pengaruh Jenis Kelamin, Latar belakang Pendidikan dan Pekerjaan Orang Tua terhadap Hasil Belajar pada Program Studi Pendidikan Pancasila dan Kewarganegaraan Institut Keguruan dan Ilmu Pendidikan Persatuan Guru Republik Indonesia Pontianak “.

Berdasarkan uraian di atas, tujuan penelitian ini adalah untuk mengetahui: (1) perbedaan hasil belajar antara mahasiswa dan mahasiswi; (2) perbedaan hasil belajar antara mahasiswa/i yang berlatar belakang pendidikan sekolah menengah negeri dan sekolah menengah swasta; (3) perbedaan hasil belajar antara mahsiswa/i yang pekerjaan orang tuanya pegawai negeri dan Pegawai (karyawan) swasta; (4) pengaruh interaksi antara jenis kelamin dan latar belakang pendidikan terhadap hasil belajar mahasiswa/I; (5) pengaruh interaksi antara jenis kelamin dan jenis pekerjaan orang tua terhadap hasil belajar mahasiswa/i; (6) pengaruh interaksi antara latar belakang pendidikan dengan pekerjaan orang tua terhadap hasil belajar mahasiswa/I; (7) pengaruh interaksi antara jenis kelamin, latar belakang pendidikan dan pekerjaan orang tua terhadap hasil belajar mahasiswa/i.

\section{METODOLOGI PENELITIAN}

Metode yang digunakan dalam penelitian ini metode ex post facto dengan disain factorial $2 \times 2 \times 2$. Variabel penelitian terdiri dari variabel bebas, variabel terikat dan variabel kontrol. Variabel bebas dalam penelitian ini adalah terdiri dari : (a) Jenis kelamin (b) Latar belakang Pendidikan dan c) Pekerjaan Oang Tua. Variabel terikat adalah hasil belajar. Sedangkan variabel kontrol adalah: (a) Tahun perkuliahan akademik 2012-2013 (b) Hasil belajar semester dua.

Populasi dalam penelitian ini adalah seluruh mahasiswa program studi PPKn dengan karekteristiknya: (a) Mahasiwa semester genap tahun akademik 2012-2013; (b) Mahasiswa semester II; (c) Mahasiswa kelas pagi; (d) Mahasiswa yang terherigistrasi dan mengikuti ujian semester. 
Sesuai dengan tujuan penelitian ini yaitu ingin mencari pengaruh jenis kelamin, latar belakang pendidikan dan pekerjaan orang tua terhadap hasil belajar mahasiwa-mahasiswi program studi PKn dengan cara membandingkan, maka populasi penelitian dikelompokan menjadi 4 kelompok yaitu: (a) kelompok mahasiswa, latar belakang pendidikan Sekolah Menengah Negeri dan pekerjaan orang tua pegawai negeri; (b) Kelompok mahasiswa, latar belakang pendidikan Sekolah Menengah Swasta dan pekerjaan orang tua Karyawan Swasta; (c) Kelompok mahasiswi latar belakang pendidikan Sekolah Menengah Negeri dan pekerjaan orang tua pegawai negeri dan (d) Kelompok Mahasiswi latar belakang pendidikan Sekolah Menengah Swasta dan pekerjaan orang tua Karyawan Swasta. Jumlah populasi secara keseluruhan 137 orang.

Penelitian ini penelitian sampel dan teknik sampling yang digunakan adalah proporsional random sampling dimana jumlah sampel ditarik secara proporsional berdasarkan jumlah kelompok pupulasi penelitian dengan cara diundi. Penentuan besar ukuran sampel ditentukan berdasarkan empat hal yang perlu dipertimbangkan: (a) Derajat keseragaman dari populasi. Makin seragam populasi itu, makin kecil populasi yang dapat diambil; (b) Presisi yang dikehendaki dari penelitian. Makin tinggi tingkat presisi yang dikehendaki, makin besar jumlah sampel yang harus diambil. Jadi sampel yang besar cenderung memberikan penduga yang lebih mendekati nilai keseluruhan; (c) Rencana analisis. Adakalanya besarnya sampel sudah mencukupi sesuai dengan presisi yang dikehendaki, tetapi kalau dikaitkan dengan kebutuhan analisis, maka jumlah sampel tersebut kurang mencukupi; (d) Tenaga, biaya, dan waktu. Bila menginginkan presisi yang tinggi, maka jumlah sampel harus besar. Tetapi apabila tenaga, biaya dan waktu terbatas, maka tidaklah mungkin untuk mengambil sampel yang besar dan ini berarti presisinya akan menurun. (Masri dan Sofian Effendi, 1989: 150).

Berdasarkan pertimbangan di atas besarnya ukuran sampel dalam penelitian ini ditetapkan sebesar 30 orang mahasiswa atau mahasiswi untuk masing-masing kelompok, sehingga jumlah sampel seluruhnya adalah 120 orang.

Teknik penelitina yang digunakan adalah teknik studi dokementer, dimana peneliti mengumpulkan data-data dokumen yang berkaitan dengan indentitas mahasiswa, latar belakang pendidikannya, pekerjaan orang tua dan prestasi belajar mahasiswa atau mahasiswi semester genap pada program studi PKn pada IKIP-PGRI Pontianak tahun akademik 2014-2015.

Karena penelitian ini bermaksud membandingkan tentang suatu kelompok dengan kelompok lain tentang sesuatu hal, dalam hal ini adalah antara kelompok menurut jenis kelamin, antara kelompok menurut latar belakang pendidikan dan antara kelompok ,menurut status 
pekerjaan orang tua, maka teknik pengolahan data yang digunakan dalam penelitian ini adalah analisa varian tiga jalan.

\section{HASIL PENELITIAN DAN PEMBAHASAN}

\section{Perbedaan Hasil Belajar antara Mahasiswa dan Mahasiswi}

Tabel Hasil Belajar Mahasiswa dan Mahasiswi

\begin{tabular}{cccc}
\hline Jenis Kelamin & Jumlah Mahasiswa & Skor Total & Rata-rata \\
\hline Mahasiswa & 32 & 101,92 & $\mathbf{3 , 1 8 5}$ \\
\hline Mahasiswi & 33 & 104,32 & $\mathbf{3 , 1 6 1}$ \\
\hline
\end{tabular}

Nilai $\mathrm{F}$ hitung $\mathrm{F}(\mathrm{A})$ menunjukan 376,9. Dengan $\mathrm{dk}$ pembilang $\mathrm{dk}(\mathrm{A})=1 \mathrm{dan} \mathrm{dk}$ penyebut $\mathrm{dk}(\mathrm{D})=56$, diketahui bahwa pada tingkat signifikansi (alpha) 0,05 nilai $\mathrm{F}$ rasio $=$ 4,04. Dengan demikian nilai $\mathrm{F}$ hitung > F rasio atau 376,9>4,04 berarti signifikan . H0 ditolak dan Ha diterima. Ini berarti terdapat perbedaan yang signifikan dalam hasil belajar antara Mahasiswa dan mahasiswi.

Berdasarkan perbedaan skor rata-rata antara antara kedua kelompok yang dibandingkan itu menunjukan bahwa skor rata-rata indek prestasi belajar pada Mahasiswa adalah 3,18 dan kelompok wanita adalah 3,16. Ini berarti bahwa kelompok Mahasiswa memiliki hasil belajar lebih tinggi atau lebih baik dari kelompok Mahasiswi.

\section{Perbedaan Hasil Belajar Berdasarkan Asal SLTA}

Tabel Hasil Belajar Berdasarkan Asal SLTA

\begin{tabular}{cccc}
\hline Jenis Kelamin & Jumlah Mahasiswa & Skor Total & Rata-rata \\
\hline SLTA Negeri & 29 & 91,57 & $\mathbf{3 , 1 5 7}$ \\
\hline SLTA Swasta & 36 & 114,77 & $\mathbf{3 , 1 8 8}$ \\
\hline
\end{tabular}

Nilai $F$ hitung $F(B)$ menunjukan 380, 7. Dengan dk pembilang $\mathrm{dk}(\mathrm{B})=1 \mathrm{dan} \mathrm{dk}$ penyebut $\mathrm{dk}(\mathrm{D})=56$, diketahui bahwa pada tingkat signifikansi (alpha) 0,05 nilai $\mathrm{F}$ rasio $=$ 4,04. Dengan demikian nilai $\mathrm{F}$ hitung > F rasio atau 380,7>4,04 berarti signifikan . H0 ditolak dan Ha diterima. Ini berarti terdapat perbedaan yang signifikan dalam hasil belajar antara Mahasiswa dan mahasiswi yang berasal dari SLTA Negeri dan mahasiswa dan mahasiwi yang berasal dari SLTA swasta.

Berdasarkan perbedaan skor rata-rata antara antara kedua kelompok yang dibandingkan itu menunjukan bahwa skor rata-rata indek prestasi belajar kelompok mahasiswa dan mahasiswi yang berasal dari SLTA Negeri 3,15 dan kelompok mahasiswa dan mahasiswi yang bersalal dari SLTA swasta 3,18. Ini berarti bahwa kelompok mahasiswa 
dan mahasiswi yang berasal dari SLTA negeri hasil belajarnya lebih rendah dari hasil belajar kelompok mahasiswa dan mahasiswi yang berasal dari SLTA swasta.

\section{Perbandingan Hasil Belajar Berdasarkan Pekerjaan Orang Tua}

Tabel Hasil Belajar Berdasarkan Pekerjaan Orang Tua

\begin{tabular}{cccc}
\hline Jenis Kelamin & Jumlah Mahasiswa & Skor Total & Rata-rata \\
\hline Pegawai Negeri & 14 & 48,2 & $\mathbf{3 , 4 4 2}$ \\
\hline Pegawai Swasta & 50 & 158,06 & $\mathbf{3 , 1 6 1}$ \\
\hline
\end{tabular}

Nilai $F$ hitung $\mathrm{F}(\mathrm{C})$ adalah 632, 9. Dengan dk pembilang $\mathrm{dk}(\mathrm{C})=1 \mathrm{dan} \mathrm{dk}$ penyebut $\mathrm{dk}(\mathrm{D})=56$, dapat diketahui bahwa pada tingkat signifikansi (alpha) 0,05, $\mathrm{F}$ rasio $=4,04$. Dengan demikian nilai $\mathrm{F}$ hitung $>\mathrm{F}$ rasio atau 632,9>4,04 berarti signifikan H0 ditolak dan Ha diterima. Ini berarti terdapat perbedaan yang signifikan dalam hasil belajar antara Mahasiswa dan mahasiswi yang pekerjaan orang tuanya Pegawai Negeri dan mahasiswa dan mahasiwi yang pekerjaan orang tuanya Pegawai Swasta.

Berdasarkan perbedaan skor rata-rata antara antara kedua kelompok yang dibandingkan itu menunjukan bahwa skor rata-rata indek prestasi belajar kelompok mahasiswa dan mahasiswi yang pekerjaan orang tuanya Pegawai Negeri 3,44 dan kelompok mahasiswa dan mahasiswi yang pekerjaan orang tuannya Pegawai Swasta 3,16. Ini berarti bahwa kelompok mahasiswa dan mahasiswi yang pekerjaan orang tuanya Pegawai Negeri hasil belajarnya lebih tinggi dari hasil belajar kelompok mahasiswa dan mahasiswi yang pekerjaan orang tuanya Pegawai Swasta.

4. Perbedaan hasil belajar berdasarkan jenis kelamin dan Asal Sekolah

Tabel Hasil Belajar Berdasarkan Jenis Kelamin dan Asal Sekolah

\begin{tabular}{|c|c|c|c|c|c|c|}
\hline \multirow{2}{*}{$\begin{array}{c}\text { Jenis } \\
\text { Kelamin }\end{array}$} & \multicolumn{3}{|c|}{ SLTA Negeri } & \multicolumn{3}{c|}{ SLTA Swasta } \\
\cline { 2 - 7 } & Jumlah & $\begin{array}{c}\text { Jumlah } \\
\text { Skor }\end{array}$ & Rata-rata & Jumlah & $\begin{array}{c}\text { Jumlah } \\
\text { Skor }\end{array}$ & Rata-rata \\
\hline Mahasiswa & 14 & 45,14 & $\mathbf{3 , 2 2 4}$ & 18 & 56,78 & $\mathbf{3 , 1 5 4}$ \\
\hline Mahasiswi & 14 & 43,33 & $\mathbf{3 , 0 9 5}$ & 18 & $\mathbf{5 7 , 9 9}$ & $\mathbf{3 , 2 2 1}$ \\
\hline
\end{tabular}

Nilai $F$ hitung $F(A B)$ adalah $-386,1$. Dengan $d k$ pembilang $d k(A B)=1 \mathrm{dan} d k$ penyebut $\operatorname{dk}(\mathrm{D})=56$, dapat diketahui bahwa pada tingkat signifikansi (alpha) 0,05, F rasio = 4,04. Dengan demikian nilai F hitung < F rasio atau -386,1 >4,04 berarti non signifikan . H0 diterima dan Ha ditolak. ini berarti tidak terdapat perbedaan yang signifikan dalam hasil belajar berdasarkan interaksi jenis kemamin dan asal sekolah.

Berdasarkan perbedaan skor rata-rata antara antara kedua kelompok yang dibandingkan itu menunjukan bahwa skor rata-rata indek prestasi belajar kelompok 
mahasiswa yang berasal dari SLTA Negeri 3,22 dan kelompok mahasiswa dari SLTA Swasta 3,15. Ini berarti bahwa kelompok mahasiswa yang berasal dari SLTA Negeri lebih baik hasil belajarnya dari pada kelompok mahasiswa yang berasal dari SLTA Swasta.. Skor rata-rata indek prestasi belajar kelompok mahasiswa yang berasal dari SLTA Swasta 3,15. Kelompok mahasiswi yang berasal dari SLTAA Negeri rata rata hasil belajar 3,09 dan kelompok mahasiswimdari SLTA Swasta rata rata hasil belajar 3,22. Ini berarti bahwa kelompok mahasisw yang berasal dari SLTA Swasta lebih tinggi dari hasil belajarnya dari pada kelompok mahasiswi berasal dari SLTA Negeri.

\section{Perbedaan Hasil Belajar Berdasarkan Jenis Kelamin dan Pekerjaan Orang Tua}

Tabel Hasil Belajar Berdasarkan Jenis Kelamin dan Asal Sekolah

\begin{tabular}{|c|c|c|c|c|c|c|}
\hline \multirow{2}{*}{$\begin{array}{c}\text { Jenis } \\
\text { Kelamin }\end{array}$} & \multicolumn{3}{|c|}{ Pegawai Negeri } & \multicolumn{3}{c|}{ Pegawai Swasta } \\
\cline { 2 - 7 } & Jumlah & $\begin{array}{c}\text { Jumlah } \\
\text { Skor }\end{array}$ & Rata-rata & Jumlah & $\begin{array}{c}\text { Jumlah } \\
\text { Skor }\end{array}$ & Rata-rata \\
\hline Mahasiswa & $\mathbf{7}$ & $\mathbf{2 2 , 6 9}$ & $\mathbf{3 , 2 4 1}$ & $\mathbf{2 5}$ & $\mathbf{7 9 , 2 3}$ & $\mathbf{3 , 1 6 9}$ \\
\hline Mahasiswi & $\mathbf{7}$ & $\mathbf{2 2 , 4 9}$ & $\mathbf{3 , 2 1 2}$ & $\mathbf{2 5}$ & $\mathbf{7 8 , 8 3}$ & $\mathbf{3 , 1 5 3}$ \\
\hline
\end{tabular}

Nilai $\mathrm{F}$ hitung $\mathrm{F}(\mathrm{AC})$ adalah $-259,4$. Dengan $\mathrm{dk}$ pembilang $\mathrm{dk}(\mathrm{AC})=1 \mathrm{dan} \mathrm{dk}$ penyebut $\mathrm{dk}(\mathrm{D})=56$, dapat diketahui bahwa pada tingkat signifikansi (alpha) 0,05, F rasio = 4,04. Dengan demikian nilai F hitung < F rasio atau $-259.4<4,04$ berarti non signifikan . H0 diterima dan Ha ditolak. Ini berarti tidak terdapat perbedaan yang signifikan dalam hasil belajar berdasarkan interaksi jenis kelamin dan pekerjaan orang tua

Berdasarkan perbedaan skor rata-rata antara kedua kelompok yang dibandingkan itu menunjukan bahwa rata-rata indek prestasi belajar kelompok mahasiswa yang pekerjaan orang tuanya Pegawai Negeri 3,24 dan kelompok mahasiswi 3,21. Ini berarti bahwa tidak perbedaan signifikan hasil belajar antara kelompok mahasiswa dan mahasiswi yang pekerjaan orang tuanya Pegawai Negeri.

Sedangkan indek prestasi belajar kelompok mahasiswa yang pekerjaan orang tuanya Pegawai Swasta 3,17 dan kelompok mahasiswi 3,15. Ini berarti bahwa tidak ada perbedaan yang signifikan hasil belajar antara mahasiswa putra mahasiswi yang pekerjaan orang tunaya sebagai Pegawai Swasta.

\section{Perbedaan Hasil Belajar Asal Sekolah dan Pekerjaan Orang Tua}

Tabel Hasil Belajar Berdasarkan Asal Sekolah dan Pekerjaan Orang Tua

\begin{tabular}{|c|c|c|c|c|c|c|}
\hline \multirow{3}{*}{ Asal Sekolah } & \multicolumn{3}{|c|}{ Pegawai Negeri } & \multicolumn{3}{c|}{ Pegawai Swasta } \\
\cline { 2 - 6 } & Jumlah & $\begin{array}{c}\text { Jumlah } \\
\text { Skor }\end{array}$ & Rata-rata & Jumlah & $\begin{array}{c}\text { Jumlah } \\
\text { Skor }\end{array}$ & Rata-rata \\
\hline
\end{tabular}




\begin{tabular}{|c|c|c|c|c|c|c|}
\hline SLTA Negeri & $\mathbf{8}$ & $\mathbf{2 6 , 5}$ & $\mathbf{3 , 3 1 2}$ & $\mathbf{2 0}$ & $\mathbf{6 2 , 2}$ & $\mathbf{3 , 1 1}$ \\
\hline SLTA Swasta & $\mathbf{6}$ & $\mathbf{1 8 , 9 1}$ & $\mathbf{3 , 1 5 1}$ & $\mathbf{3 0}$ & $\mathbf{9 5 , 8 6}$ & $\mathbf{3 , 1 9 5}$ \\
\hline
\end{tabular}

Nilai $\mathrm{F}$ hitung $\mathrm{F}(\mathrm{BC})$ adalah $-210,4$. Dengan $\mathrm{dk}$ pembilang $\mathrm{dk}(\mathrm{BC})=1 \mathrm{dan} \mathrm{dk}$ penyebut $\mathrm{dk}(\mathrm{D})=56$, dapat diketahui bahwa pada tingkat signifikansi (alpha) 0,05, F rasio = 4,04. Dengan demikian nilai $\mathrm{F}$ hitung $<\mathrm{F}$ rasio atau $-210,4<4,04$ berarti signifikan . H0 diterima dan Ha ditolak. Ini berarti tidak terdapat perbedaan yang signifikan dalam hasil belajar berdasarkan interaksi asal sekolah dan pekerjaan orang tua.

Rata-rata indek prestasi kelompok mahasiswa dan mahasiswi yang berasal dari SLTA negeri dan pekerjaan orang tuanya pegawai negeri 3.31 dan pekerjaan orang tua pegawai swasta 3,11. Ini berarti hasil belajar mahasiswa dan mahasiswa yang pekerjaan orang tuanya pegawai negeri lebih baik dari yang orang tuanya pegawai swasta.

Sedangkan rata-rata indek prestasi kelompok mahasiswa dan mahasiswi yang berasal dari SLTA swasta dan pekerjaan orang tuanya pegawai negeri 3.15 dan pekerjaan orang tua pegawai swasta 3,19. Ini berarti hasil belajar mahasiswa dan mahasiswa yang pekerjaan orang tuanya pegawai negeri lebih rendah dari yang orang tuanya pegawai swasta.

7. Perbedaan Hasil Belajar Berdasarkan Jenis kelamin, Asal Sekolah dan Pekerjaan Orang Tua

Tabel Hasil Belajar Jenis Kelamin, Asal Sekolah dan Pekerjaan Orang tua

\begin{tabular}{|c|c|c|c|c|}
\hline \multirow{2}{*}{ Jenis } & \multicolumn{2}{|c|}{ SLTA Negeri } & \multicolumn{2}{c|}{ SLTA Swasta } \\
\cline { 2 - 5 } Kelamin & Peg. Negeri & Peg. Swasta & Peg. Negeri & Peg. Swasta \\
\hline Mahasiswa & $\mathbf{3 , 3 1 2}$ & $\mathbf{3 , 1 8 9}$ & $\mathbf{3 , 1 4 6}$ & $\mathbf{3 , 1 5 6}$ \\
\hline Mahasiswi & $\mathbf{3 , 2 2 5}$ & $\mathbf{3 , 0 3 1}$ & $\mathbf{3 , 1 5 6}$ & $\mathbf{3 , 2 3 4}$ \\
\hline
\end{tabular}

Nilai $F$ hitung $\mathrm{F}(\mathrm{ABC})$ adalah $-708,2$. Dengan dk pembilang $\mathrm{dk}(\mathrm{ABC})=1 \mathrm{dan} \mathrm{dk}$ penyebut $\mathrm{dk}(\mathrm{D})=56$, dapat diketahui bahwa pada tingkat signifikansi (alpha) $0,05, \mathrm{~F}$ rasio $=$ 4,04. Dengan demikian nilai F hitung < F rasio atau $-708,2<4,04$ berarti non signifikan . H0 diterima dan Ha ditolak. ini berarti tidak terdapat perbedaan yang signifikan dalam hasil belajar berdasarkan interaksi jenis kelamin, asal sekolah dan pekerjaan orang tua

Rata-rata indek prestasi belajar kelompok mahasiswa berasal dari SLTA Negeri dan pekerjaan orang tua Pegawai negeri 3,31. Sedangkan rata-rata hasil belajar kelompok mahasiswa yang berasal dari SLTA Negeri dan pekerjaan orang tua pegawai swasta 3,18. Ini berarti hasil belajar mahasiswa asal SLTA Negeri pekerjaan orang tua pegawai negeri lebih baik dari pada pekerjaan orang tua pegawai Swasta.

Rata-rata indek prestasi belajar kelompok mahasiswi yang berasal dari SLTA negeri dan pekerjaan orang tua pegawai Negeri 3,22 dan kelompok mahasiswi asal SLTA Negeri dan pekerjaan orang tuanya pegawai swasta 3,03. Ini berarti hasil belajar mahasiswi asal 
SLTA Negeri dan pekerjaan orang tua pegawai negeri lebih baik dari. SLTA Negeri pekerjaan orang tua pegawai swasta.

Rata-rata indek prestasi belajar kelompok mahasiswa dari SLTA swasta, pekerjaan orang tua pegawai pegawai negeri 3.14 dan rata rata indek prestasi kelompok mahasiswa asal SLTA swasta dan pekerjaan orang pegawai swasta 3,15. Ini berarti tidak ada perbedaan siginifikan hasil belajar mahasiswa yang berasal dari SLTA swasta pekerjaan orang tua pegawai dengan pekerjaan oran tua pegawai swasta.

Rata-rata indek prestasi belajar kelompok mahasiswi berasal dari SLTA swasta pekerjaan orang tua pegawai negeri 3,15 dan kelompok mahasiswi asal SLTA swasta dan pekerjaan orang tua pegawai swasta 3,23. Ini berarti hasil belajar mahasiswi asal dari SLTA swasta pekerjaan orang tua pegawai negeri lebih rendah dari mahasiswi asal SLTA swasta asiswa pekerjaan orang tuanya pegawai swasta.

\section{SIMPULAN}

Berdasarkan hasil pengolahan data, maka dapat simpulkan hasil penelitian ini sesuai dengan rumusan masalah sebagai brikut:

1. Terdapat perbedaan yang signifikan, hasil belajar antara siswa Mahasiswa dan mahasiswi. Mahasiswa memiliki hasil belajar lebih tinggi atau lebih baik dari kelompok Mahasiswi.

2. Terdapat perbedaan yang signifikan, hasil belajar antara Mahasiswa dan mahasiswi berasal dari SLTA Negeri dan mahasiswa dan mahasiwi berasal dari SLTA swasta. Kelompok mahasiswa dan mahasiswi yang berasal dari SLTA negeri hasil belajarnya lebih rendah dari hasil belajar kelompok mahasiswa dan mahasiswi yang berasal dari SLTA swasta.

3. Terdapat perbedaan yang signifikan, hasil belajar antara Mahasiswa dan mahasiswi yang pekerjaan orang tuanya Pegawai Negeri dan mahasiswa dan mahasiwi yang pekerjaan orang tuanya Pegawai Swasta. Kelompok mahasiswa dan mahasiswi yang pekerjaan orang tuanya Pegawai Negeri hasil belajarnya lebih tinggi dari hasil belajar kelompok mahasiswa dan mahasiswi yang pekerjaan orang tuanya Pegawai Swasta.

4. Tidak terdapat perbedaan yang signifikan, hasil belajar mahasiswa dan mahasiswi berdasarkan interaksi jenis kelamin dan asal sekolah

5. Tidak terdapat perbedaan yang signifikan, hasil belajar mahasiswa dan maahasiswi berdasarkan interaksi jenis kelamin dan pekerjaan orang tua

6. Tidak terdapat perbedaan yang signifikan, hasil belajar berdasarkan interaksi asal sekolah dan pekerjaan orang tua. 
7. Tidak terdapat perbedaan yang signifikan, hasil belajar mahasiswa dan mahasiswi berdasarkan interaksi jenis kelamin, asal sekolah dan pekerjaan orang tua.

\section{DAFTAR PUSTAKA}

Anna Marie attie (1996), “ Gender Hak Reproduksi, dan Pelayanan Keluarga Barencana” dalam Agus Dwiyanto, Faturrochman, Marcelinus Molo, Irwan Abdullah, (Ed): Penduduk dan Pembangunan. Yogyakarta: Pusat Penelitian Kependudukan Universitas Gajah Mada.

Depdikbud, (1983) Proyek Normalisasi Kehidupan Kampus, Petunjuk Pelaksanaan Sistem Kridit Semester Untuk Perguruan Tinggi. Jakarta: Dirjen Dikti.

Fudyartanta, (1971), Inti Sari Psikologi Perkembangan I. Yogyakarta: Warawydiarni

Masri Singarimbun dan Sofian Effendi, (1989), Metode Penelitian Survey. Jakarta: LP3ES

Masrun dan Sri Mulyani Martaniah, (1976), Psikologi Pendidikan. Yogyakarta: Fakultas Psikologi UGM

Rudiana, (2012), Karekter Guru Menyenangkan Berbasis Ramah Otak. Bandung: Smaile's Indonesia Institute(SII) Publishing

Siswaatmadja, (1979), Didaktik Kurikulum. Pontianak: FIP-UNTAN

Zuldafrial, (2011), Startegi Belajar- Mengajar. Pontianak: STAIN Pontianak Press

, (2004), " Hubungan Sosial Ekonomi Orang Tua dengan Kualitas Proses BelajarMengajar Siswa di Sekolah, Studi Kasus di Desa Sunga Itik, Kecamatan Sungai Kakap Kabupaten Pontianak “, Edukasi Jurnal Pendidikan, Vol.2 No.2 Oktober, STKIP-PGRI Pontianak.

, (2002), “Hubungan Sosial Ekonomi Orang Tua dengan dengan Kepedulian Orang Tua Terhadap Pendidikan Anak di Sekolah (Studi Kasus Kecamatan Sukadana) “, Wawasan Majalah Ilmiah Kopertis Wilayah XI Kalimantan, Vol.10 No. 3 Oktober 